\title{
Doctoral Dissertations on Russia, the Soviet Union, Central Asia, and Eastern Europe Accepted by Universities in the United States and Canada, 2017
}

\author{
Patricia K. Thurston
}

This list, covering dissertations in the social sciences, humanities, and fine arts, was compiled through systematic searching in ProQuest's Dissertations \& Theses database, as well as OCLC WorldCat, and other university library catalogs. The current list for 2017 contains 133 titles from 72 universities and covers titles that were available for electronic database searching from September 2017 to July 2018.

A list of dissertations, through 1959, can be found in Jesse J. Dossick's Doctoral Research on Russia and the Soviet Union (New York, 1960) and, through 1975, in the accompanying volume, Doctoral Research on Russia and the Soviet Union, 1960-1975 (New York, 1976). The second volume contains more than three thousand titles that have appeared in the Slavic Review's annual list since 1964 (the 1964 list also included dissertations accepted from 1960 to 1963), as well as items not previously included in the first volume. In addition, the second volume offers some critical and statistical analysis, more than thirty major classifications, numerous subclassifications and subsubclassifications, cross-references, an index of Russian and Soviet names, and an index of authors. A list of dissertations from 1976 to 1991 may be found in the winter issues of Slavic Review through the year 1992.

\section{RUSSIA, THE USSR, AND THE FORMER USSR}

\section{Archaeology}

Sharapov, Denis V. "Bronze Age Settlement Patterns and the Development of Complex Societies in the Southern Ural Steppes (3500-1400 BC).” Pittsburgh, 2017.

\section{Architecture and Urban Planning}

Bokov, Anna. "Teaching Architecture to the Masses: Vkhutemas and the Pedagogy of Space, 1920-1930.” Yale, 2017.

\section{Art History}

Bokov, Anna. See Architecture and Urban Planning.

Helprin, Alexandra. "The Sheremetevs and the Argunovs: Art, Serfdom, and Enlightenment in Eighteenth-Century Russia.” Columbia, 2017. 


\section{Ballet}

Zale, Jennifer Ann. "Bolshoi Ballerina Vera Karalli: Russia’s First Film Star, the ImperialEra Dance Film, and the Modernization of Cinema Going Practices and Perceptions in Prerevolutionary Russia.” Indiana, 2017.

\section{Business and Management Practices}

Cholacu, Anastasia. “The Relationship between Government and the Private Energy Sector in Russia: A Multiple Case Study.” Northcentral, 2017.

\section{Cinema and Film Studies}

Vinogradova, Maria. "Amateur Cinema in the Soviet Union: History, Ideology and Culture.” New York, 2017.

Zale, Jennifer Ann. See Ballet.

\section{Drama}

Avkhimovich, Irina Sergeyevna. See Literature.

\section{Economics}

Cohen, Mark. "A Bridge of Rice and Silk, a Wall of Wheat and Rye: Reforming States and Agrarian Change in Japan and Russia, 1853-1913.” New York, 2017.

Goetz, Daniel T. “Essays on Market Structure and Product Quality.” Princeton, 2017.

Ponomareva, Ekaterina A. "The Health and Labor Market Effects of Spouse Choice, Maternity Leave and Parental Work.” Lehigh, 2017.

\section{Education}

Paulic, Deniz Jacqueline. "Pilot Trial of a Knowledge Sharing Intervention Program with Digital Games.” Phoenix, 2017.

Rekhter, Natalia. "International Students' use of Social Network Sites for College Choice Activities and Decision Making.” Indiana, 2017.

\section{Émigré and Immigration Studies}

Yolacan, Serkan. See Caucasus, Azerbaijan.

Yurguis, Katia. "Close to God and Far from the USSR: Religious Choices and Immigrant Identities among Russians in New York City.” Fordham, 2017.

\section{Ethnic and Minority Studies}

Kushkova, Anna. "Navigating the Planned Economy: Accommodation and Survival in Moscow’s Post-War 'Soviet Jewish Pale.”' North Carolina, Chapel Hill, 2017.

Levy, Stephanie B. "Human Energetics in a Changing Climate: Health, Lifestyle, and Adaptation among the Yakut of Northeastern Siberia.” Northwestern, 2017.

Zaides, Sarah Michelle. “Tevye’s Ottoman Daughter: The Making of Ashkenazi and Sephardi Jews in the Shatterzones of Empire, 1882-1923.” Washington, 2017. 


\section{Geography}

Hall, Joanne V. "Quantifying Variability of Black Carbon Transport from Cropland Burning in Russia to the Arctic Driven by Atmospheric Blocking Events.” Maryland, College Park, 2017.

Kontar, Yekaterina Y. "Comparative Analysis of Spring Flood Risk Reduction Measures in Alaska, United States and the Sakha Republic, Russia.” Alaska, Fairbanks, 2017.

\section{History}

To 1800

Helprin, Alexandra. See Art History.

Soviet History, Politics, Political Thought, and Nationality Policy

Bartel, Michael Frederic. "The Triumph of Broken Promises: Oil, Finance, and the End of the Cold War.” Cornell, 2017.

Dowling, Rhiannon Lee. “Brezhnev's War on Crime: The Criminal in Soviet Society, 19631984.” California, Berkeley, 2017.

Morton, Jason Read. See Literature.

Radtke, Mitchell Thomas. "Dictators, Ministerial Cronyism, and International Conflict." Texas A\&M, 2017.

\section{Spain and the Soviet Union}

Sherry, Jonathan. "Stalinism on Trial: Spanish Republican Legality, the Soviet Union, and the Performance of Justice in the Spanish Civil War, 1936-1939.” Pittsburgh, 2017.

\section{United States and the Soviet Union}

Berenji, Shahin. "Accepting Risks and Making Bold Gestures: Why Decision-Makers Initiate Conciliation in Rivalries.” California, Los Angeles, 2017.

Davis, Aaron Kai. See Images of the Soviet Union, Russia, and Eastern Europe in Other Regions of the World.

Feygin, Yakov. "Reforming the Cold War State: Economic Thought, Internationalization, and the Politics of Soviet Reform, 1955-1985.” Pennsylvania, 2017.

Yugoslavia and the Soviet Union

Perez, Daniel Isaac. See Albania.

\section{Post-Soviet History, Politics, Political Thought, and Nationality Policy}

Albinali, Abdulaziz. “Oil Policy \& Elites Political Survival: Determinants \& Consequences of Oil Sector Ownership Structure.” Claremont Graduate, 2017.

Buckley, Noah Matthew. "Calculating Corruption: Political Competition and Bribery Under Authoritarianism.” Columbia, 2017.

Citrinn, Paul. "Ending the Cold War on the Cheap the George H. W. Bush Administration and the Issue of Western Financial Aid to Perestroika, 1989-1991.” New School, 2017.

Degirmen, Burcu. "Opposition to Authoritarianism: Ideational and Material Resources in Russia and Ukraine.” Oklahoma, 2017.

Dzutsati, Valery. "The Origins of Secessionist Violence: Culture, Redistribution, and Security.” Arizona State, 2017.

Klyueva, Anna. "Strategic Narratives of Public Diplomacy and the Enactment of Soft Power: An Exploratory Study.” Oklahoma, 2017. 
Krylova, Yulia. “'Grease’ Payments in the Relations between Individual Entrepreneurs and Regulatory Agencies: The Case of Russia." George Mason, 2017.

Vorobyeva, Yulia. "How Regimes Shape Organized Crime: Mexico and Russia during Political Transitions.” Miami, 2017.

\section{Language and Linguistics}

Schell, Tatjana. “'Dear Children, Jacob and Amalie’: A Rhetorical Analysis of Letters from Russia to a Volga German Immigrant Couple in the American Midwest." North Dakota State, 2017.

\section{Literature}

Avkhimovich, Irina Sergeyevna. "Performing the National Past: History on Stage in Imperial Russia.” Illinois, Urbana-Champaign, 2017.

Morton, Jason Read. “The Creation of a 'People’s Hero': Vasilii Ivanovich Chapaev and the Fate of Soviet Popular History.” California, Berkeley, 2017.

Schell, Tatjana. See Language and Linguistics.

Sutton, Matthew A. "Old Turths in New Skins: Animal Imagery in the Works of Nikolai Leskov.” Illinois, Urbana-Champaign, 2017.

Wilkins, Evgenia Mikhaylova. "Exploring Change: Oral Metadiscourse of Advanced Learners of Russian in Extended Study Abroad.” Texas, Austin, 2017.

\section{Mass Media}

Stokes, Ethan Christopher. "A Global Election: Analyses of Chinese, Russian, and Saudi Arabian News Coverage of the 2016 U.S. Presidential Election.” Alabama, 2017.

\section{Music}

Birch, Alexandra. "Balancing Mathematics and Virtuosity: A Performer's Guide to Sofia Gubaidulina's Dancer on a Tightrope.” Arizona State, 2017.

Blachnio, Filip. "The Evolution of Musical Language and Sonata Form in the Piano Sonatas of Alexander Nikolayevich Scriabin.” Rice, 2017.

Bonner, Elise Lauren. "Catherine the Great and the Rise of Comic Opera in Late Eighteenth-Century St. Petersburg.” Princeton, 2017.

Džinović, Branko. "The Composer-Performer Interrelationship in the Bayan and Accordion Compositions of Sofia Gubaidulina.” Toronto, Canada, 2017.

Eichner, Solomon. “The Life and Legacy of Samuil Feinberg.” South Carolina, 2017.

Gorbunova, Tatiana. "A Piano Sonata and 24 Preludes for Piano: Old Forms in the New Context.” Florida State, 2017.

Gravelle, Shannon Marie. "A Preliminary Study of the Choral Works and Style of Sergei Taneyev.” Iowa, 2017.

Mullinger, Lisa N. "Giving Voice to a Nation: Choral Music and Russian Identity in St. Petersburg, 1861-1913.” Kansas, 2017.

Perry, Rebecca A. “Thematic Idiosyncrasy in Prokofiev’s Early Sonata Forms.” Yale, 2017.

Stuart, Morgan David. "Sergei Rudnev and a Discussion of Selected Works from The Russian Collection Volume III.” Florida State, 2017.

Willey, Kristina E. "Three Dissertation Viola Recitals: British Miniatures, the Wartime Viola, and Transcriptions of Vadim Borisovsky.” Michigan, 2017. 


\section{Public Health}

Shpenev, Alexey. "Three Essays on Social Context, Education, and Health Outcomes among Older Adults.” Pennsylvania, 2017.

\section{Religion and Religious History}

Chervonenko, Sergey. "Stewardship in the Church: The Theology and Practice of Tithing, Offerings, and Stewardship in Evangelical Churches of Russia.” Asbury Theological Seminary, 2017.

Grishin, Evgeny. "Becoming a Schismatic: The Concepts of the 'Schism' and 'Schismatic' in the Church and State Discourses of Seventeenth and Eighteenth-Century Russia." Kansas, 2017.

Guzik, Michael A. "Lux Occidentale: The Eastern Mission of the Pontifical Commission for Russia, Origins to 1933.” Wisconsin, Milwaukee, 2017.

Rose, Justin Richard. See Central, South Central, and Eastern Europe. General Coverage.

Silano, Francesca. “'In the Language of the Patriarch': Patriarch Tikhon, the Russian Orthodox Church, and the Soviet State (1865-1925).” Toronto, Canada, 2017.

Todd, Meagan Lucinda. "Political Geographies of Religions in Russia: Mosques, Churches, the State, and Social Movements in Moscow.” Colorado, Boulder, 2017.

Wood, Nathaniel Kyle. "Deifying Democracy: Liberalism and the Politics of Theosis." Fordham, 2017.

Yurguis, Katia. See Émigré and Immigration Studies.

\section{Women's Studies}

Battalova, Alfiya. "Reproductive Citizenship: Experiences of Mothers with Disabilities in Russia.” Illinois, Chicago, 2017.

Klots, Alissa. "The Kitchen Maid that Will Rule the State: Domestic Service and the Soviet Revolutionary Project, 1917-1941.” Rutgers, 2017.

Konstantinovskaia, Natalia. "Real and Imagined Women's Voices in Russian and Japanese Societies: Media, Self-Perceptions, and Everyday Language Practices.” California, Los Angeles, 2017.

\section{Baltic States (Estonia, Latvia, Lithuania, and Other Baltic Regions under Russian Control)}

\section{Estonia}

Sutton, Brett R. "Parallel Architecture, Parallel Acquisition Cross-Linguistic Evidence from Nominal and Verbal Domains.” Georgetown, 2017.

\section{Lithuania}

Abe, Hiroaki. See Poland.

Payne, William R. "Why we can't Wait: An Identity Account of Nonviolent Civil Disobedience.” New School, 2017.

\section{Caucasus Region}

\section{General Coverage}

Musgrave, Megan Leone. “Empires, Environment, Islam: North Caucasus 'Mountaineers' in Revolution and War, 1905-1926.” Indiana, 2017. 
Thelen, Austen. "Regional Identity and Constructive Regionalization in the North Caucasus: Group Perceptions and Nuances from Inside the Region.” Kansas, 2017.

\section{Armenia}

Akaragian, Salpy. “The Prevalence of High Blood Pressure in Armenians.” California, Los Angeles, 2017.

Julfayan-Gregorian, Verzhine. "Success Strategies of First-Generation Foreign-Born Leaders.” Pepperdine, 2017.

Okesson, Katherine Anne. See Images of the Soviet Union, Russia, and Eastern Europe in Other Regions of the World.

\section{Azerbaijan}

Nugent, Selin Elizabeth. "Pastoral Mobility and the Formation of Complex Settlement in the Middle Bronze Age Şərur Valley, Azerbaijan.” Ohio State, 2017.

Sicotte, Jonathan H. “Baku: Violence, Identity, and Oil, 1905-1927.” Georgetown, 2017.

Yolacan, Serkan. "Order Beyond Borders: The Azerbaijani Triangle Across Iran, Turkey, and Russia.” Duke, 2017.

\section{Republic of Georgia}

Levin, Irina. "Uncertain Returns: Citizenship and Law in the Caucasus.” New York, 2017.

\section{Central Asia}

General Coverage

Ziad, Waleed. "Traversing the Indus and the Oxus: Trans-Regional Islamic Revival in the Age of Political Fragmentation and the ‘Great Game’ 1747-1880.” Yale, 2017.

\section{Kazakhstan}

Barker, Meghanne M. "Framing the Fantastic: Animating Childhood in Contemporary Kazakhstan.” Michigan, 2017.

\section{Kyrgyzstan}

Belyavina, Raisa. "Schools as Reform Changers: How Teachers and Administrators in Bishkek, Kyrgyzstan Modify Education Reforms.” Columbia, 2017.

Fleming, Jake. "Building Plant Bodies: People, Trees, and Grafting in the Walnut-Fruit Forests of Kyrgyzstan.” Wisconsin, Madison, 2017.

Peachey, Everett J. "State Sponsored Political Socialization and Public Diplomacy Exchange Program Outcomes: The Case of the Future Leaders Exchange (FLEX) Program.” Michigan, 2017.

\section{Tajikistan}

Peachey, Everett J. See Kyrgyzstan.

\section{Ukraine}

Bannan, Deborah G. "Grounded Theory Inquiry into Process of Cross-Cultural Supervision in Ukraine.” Regent, 2017.

Bogdan, Olena. "Regional Economic Growth and International Capital Flows: The Case of Ukraine.” Pardee RAND Graduate School, 2017.

Buel, Jason William. "Whose Screens? our Screens! Digital Documentary and Social Activism.” North Carolina State, 2017.

Degirmen, Burcu. See Post-Soviet History, Politics, Political Thought, and Nationality Policy. 
Jones, Deborah Alison. "Afterlives \& Other Lives: Semiosis \& History in 21st Century Ukraine.” Michigan, 2017.

Kellums Baraka, Mandy L. "Supervision Experiences of Ukrainian Counseling Students and U.S.-Trained Supervisors: A Phenomenological Inquiry.” Regent, 2017.

Kulick, Orysia Maria. "When Ukraine Ruled Russia: Regionalism and Nomenklatura Politics after Stalin, 1944-1990.” Stanford, 2017.

Ledogar, Sarah Heins. "A Zooarchaeological and Geochemical Analysis of the Faunal Remains from the Tripolye Site Verteba Cave, Ukraine.” State University of New York, Albany, 2017.

Metzger, Megan MacDuffee. "Social Media and Protest: The Changing Dynamics of Contention in the Digital Age.” New York, 2017.

Saul, Kathleen M. "The Process Model of Displacement: A Case Study Analysis of Three Nuclear Technology Projects.” Delaware, 2017.

Upchurch, Daniel. "From Riding the Wave to Swimming Against the Current: An Analysis of Factors Impacting the Numerical Growth of the all-Ukraine Union of Churches of Evangelical Christians Baptists 1991-2011.” Southwestern Baptist Theological Seminary, 2017.

\section{CENTRAL, SOUTH CENTRAL, AND EASTERN EUROPE}

\section{General Coverage}

Bartel, Michael Frederic. See Soviet History, Politics, Political Thought, and Nationality Policy.

Capani, Jennifer B. "An Alter Kämpfer at the Forefront of the Holocaust: Otto Ohlendorf between Careerism and Nazi Fundamentalism.” St. John’s, New York, 2017.

Davis, Hugh L.III. "The Impact of Commercial Banking Development on Economic Growth: A Principal Component Analysis of Association between Banking Industry and Economic Growth in Europe.” Southern Mississippi, 2017.

Healey, Beth A. "Nazi Crimes, British Justice: The Royal Warrant War Crimes Trials in British-Occupied Germany, 1945-1949.” Northwestern, 2017.

Radway, Robyn Dora. "Vernacular Diplomacy in Central Europe: Statesmen and Soldiers between the Habsburg and Ottoman Empires, 1543-1593.” Princeton, 2017.

Rose, Justin Richard. "Descending from the Throne: Byzantine Bishops, Ritual and Spaces of Authority.” California, Riverside, 2017.

Voytyuk, Mariya. "Lay Theories of Healthy Eating: Insights from Cross-Cultural Comparisons.” Arizona State, 2017.

Wasserman, Melissa M. "Psychological Symptoms, Family Functioning, and Religious Coping in Second- and Third-Generation Holocaust Survivors.” Pepperdine, 2017.

\section{Albania}

Hoxha, Luli. “Relationship between Project Managers’ Age, Years of Project Experience, and Project Success." Walden, 2017.

Lubonja, Edna. “The Arbëresh Culture: An Ace in the Hole, in the Heart of Calabria.” Florida Atlantic, 2017.

Perez, Daniel Isaac. "Between Tito and Stalin: Enver Hoxha, Albanian Communists, and the Assertion of Albanian National sovereignty, 1941-1948.” Stanford, 2017.

\section{Bulgaria}

Ivanova, Veneta Todorova. "Occult Communism: Culture, Science and Spirituality in Late Socialist Bulgaria.” Illinois, Urbana-Champaign. 
Nihtianova, Snejana. "Impact of the Childcare Setting and Caregiver Education on Toddler Language Environment.” Walden, 2017.

Petrov, Nikolay. "Robert College of Constantinople: Crossroads of Faiths, Cultures and Empires, 1863-1913.” Drew, 2017.

White, Daria Borislavova. "Being and Beholding: Comparative Analysis of Joy and Awe in Four Cultures.” James Madison, 2017.

\section{Czech Lands to 1918, Czechoslovakia, and Czech and Slovak Republics}

Rockwood, Mark F. "Form, Style, and Influence in the Chamber Music of Antonin Dvořák.” Oregon, 2017.

\section{East Germany and Germany since 1989}

Anstey, Jennifer. “Decision Processes of Emigrants from Nazi Germany.” Rochester, 2017. Blaylock, Sara. "Infiltration and Excess: Experimental Art and the East German State, 1980-1989.” California, Santa Cruz, 2017.

Horz, Carlo M. “Strategic and Psychological Foundations of Propaganda.” New York, 2017.

Klemm, Hannah Marlene. "Systems Depictions: A. R. Penck and the East German Underground, 1953-1980.” Chicago, 2017.

Piotrowska, Barbara Maria. "Covert Repression: Lessons from the Stasi Files.” Rochester, 2017.

Pulido, Michael Palmer. “Transmitting Revolution: Radio, Rumor, and the 1953 East German Uprising.” Marquette, 2017.

Schenck, Marcia Cathérine. "Socialist Solidarities and their Afterlives: Histories and Memories of Angolan and Mozambican Migrants in the German Democratic Republic, 1975-2015.” Princeton, 2017.

Smith, Briana Jennifer. "Creative Alternatives: Experimental Art and Cultural Politics in Berlin, 1971-1999.” Iowa, 2017.

Soeder, Meredith. "Jazz in a Transatlantic World: Legitimizing American Jazz in Germany, 1920-1957.” Carnegie Mellon, 2017.

Zelechowski, Jamie Leigh. "The Representation of Forced Migration in the Feature Films of the Federal Republic of Germany, German Democratic Republic, and Polish People’s Republic (1945-1970).” California, Los Angeles, 2017.

\section{Hungary}

Heck, Kalling. "Film after Authority the Transition to Democracy and the End of Politics." Wisconsin, Milwaukee, 2017.

Magyar, Lilla. "The Role of Perceptual Similarity and Gradient Phonotactic Well-Formedness in Loan Gemination Processes.” Massachusetts Institute of Technology, 2017.

Magyari, Ildiko. "Essays in Trade and Factor Markets.” Columbia, 2017.

Polónyi, Eszter. “Ghost Writer: Béla Balázs’s Hauntology of Film.” Columbia, 2017.

Sutton, Brett R. See Estonia.

\section{Poland}

Abe, Hiroaki. "Not all's Fair in Love and War: Dynasticism and Composite State Longevity in Early Modern Europe." Columbia, 2017.

Guy, Lori Jo. “'An Alphabet of Soldiers’: Jake Heggie’s Farewell, Auschwitz.” Southern Mississippi, 2017. 
Korycki, Katarzyna. "Memory as Politics: Narratives of Communism and the Shape of a Community.” Toronto, Canada, 2017.

Lesinski, Nawojka K. "When Cities Matter: Comparing the LGBT Movement in Warsaw, Poland, and Buenos Aires, Argentina.” Illinois, Chicago, 2017.

Tokarski, Kamil. "Mapping Techniques as a Means of Enhancing the Pianist's Memorization Process of Karol Szymanowski’s Masques Op.34.” Ball State, 2017.

Troy, Eddy Thomas Joseph. "Phenomenal Screens: Thinking Crisis through Film and Literature.” California, Riverside, 2017.

Wilczewski, Michal J. "Broken Land: Everyday Life and the Reconstruction of the Polish Countryside, 1914-1939.” Illinois, Chicago, 2017.

Wisniewski, Lisa M. "United States College Entry of Immigrant Students of Polish Heritage.” Hartford, 2017.

Zelechowski, Jamie Leigh. See East Germany and Germany since 1989.

\section{Romania}

Codjo, Juste E. W. “The Logic of Strategic Consensus: State Environment and Civil War." Kansas State, 2017.

Mogos, Serban Ioan. "High Growth Entrepreneurship: A Multi-Level Perspective on Firm Growth and Growth Policy." Carnegie Mellon, 2017.

Quinn, Colin P. “The Crucible of Complexity: Community Organization and Social Change in Bronze Age Transylvania (2700-1320 BC).” Michigan, 2017.

\section{Former Yugoslavia, Yugoslavia, and New Yugoslav States}

\section{General Coverage}

McCoy, Rhian. "Narrating Negative Peace: A Critical Analysis of Intelligence Support to the Dayton Peace Agreement." George Mason, 2017.

Perez, Daniel Isaac. See Albania.

Bosnia and Herzegovina

Pitic, Badema. "The Sound of Genocide: Music, Memory, and Commemoration in Postwar Bosnia.” California, Los Angeles, 2017.

Zic, Borjan. "Nationalism during Armed Conflict: A Study of Ideology and Identity in the Bosnian War, 1992-1995.” Maryland, College Park, 2017.

\section{Croatia}

Berisha, Edmond. “Monetary Policy, Economic Conditions, and Income Inequality.” West Virginia, 2017.

Kasymova, Salima. "Involvement of Men in Responsible Parenthood in Croatia, India, and Mexico: Major Factors, Correlates, and National Policy.” South Carolina, 2017.

\section{Kosovo}

Hoxha, Luli. See Albania.

Ramsey, Lisa C. "A Cultural Formation of PTSD by Ethnic Albanian Women in Kosovo: A Phenomenological Inquiry.” Regent, 2017.

\section{Serbia}

Marković, Alexander. "Gypsy Fingers are Unique! Identity Politics and Romani Musical Performance in Vranje, Serbia.” Illinois, Chicago, 2017.

\section{Slovenia}

Frie, Adrienne C. "Cultural Constructions of Nature: Animal Representation and use in Early Iron Age Southeastern Slovenia.” Wisconsin, Milwaukee, 2017. 


\section{IMAGES OF THE SOVIET UNION, RUSSIA, AND EASTERN EUROPE IN OTHER REGIONS OF THE WORLD}

Citrinn, Paul. See Post-Soviet History, Politics, Political Thought, and Nationality Policy.

Cushner, Ari N. "Cold War Comrades: Left-Liberal Anticommunism and American Empire, 1941-1968.” California, Santa Cruz, 2017.

Davis, Aaron Kai. "American Protestants and U.S. Foreign Policy Toward the Soviet Union during the Eisenhower Administration: Billy Graham, Reinhold Niebuhr, and G. Bromley Oxnam.” Kansas State, 2017.

Gould, Olga. "'Please, tell them!' Voices from College Classrooms on Effects of Resources of Multimodal Ensembles on Polylingual EAL Speaking College Students' Meaning Making of Conventional Print-Based Texts.” New York, Buffalo, 2017.

Hess, John D. "Coping with Crisis: Military Government Officials, U.S. Policy, and the Occupation of Bavaria, 1945-1949.” Kansas, 2017.

Matuskova, Magdalena. "Cuban Cinema in a Global Context: The Impact of Eastern European Cinema on the Cuban Film Industry in the 1960s." California, Los Angeles, 2017.

Okesson, Katherine Anne. "Selected Violin Works of Alan Scott 'Vaness' Chakmakjian Hovhaness: Two New Performance Editions with Historical Discussion, Compositional Style Overviews, and Pedagogical Considerations.” Kansas, 2017. 